ANL-6966

ANL-6966

Argonne Rational Laboratory

DESIGN OF A REMOTELY REMOVABLE AND REPLACEABLE CRANE-BRIDGE DRIVE UNIT FOR THE EBR-II FUEL CYCLE FACILITY by

Johan E. A. Grace 


\section{DISCLAIMER}

This report was prepared as an account of work sponsored by an agency of the United States Government. Neither the United States Government nor any agency Thereof, nor any of their employees, makes any warranty, express or implied, or assumes any legal liability or responsibility for the accuracy, completeness, or usefulness of any information, apparatus, product, or process disclosed, or represents that its use would not infringe privately owned rights. Reference herein to any specific commercial product, process, or service by trade name, trademark, manufacturer, or otherwise does not necessarily constitute or imply its endorsement, recommendation, or favoring by the United States Government or any agency thereof. The views and opinions of authors expressed herein do not necessarily state or reflect those of the United States Government or any agency thereof. 


\section{DISCLAIMER}

Portions of this document may be illegible in electronic image products. Images are produced from the best available original document. 


\section{LEGAL NOTICE}

This report was prepared as an account of Government sponsored work. Neither the United States, nor the Commission, nor any person acting on behalf of the Commission:

A. Makes any warranty or representation, expressed or implied, with respect to the accuracy, completeness, or usefulness of the information contained in this report, or that the use of any infur mation, apparatus, method, or process disclosed in this report may not infringe privately owned rights; or

B. Assumes any liabilities with respect to the use of, or for damages resulting from the use of any information, apparatus, method, or process disclosed in this report.

As used in the above, "person acting on behalf of the Commission" includes any employee or contractor of the Commission, or employee of such contractor, to the extent that such employee or contractor of the Commission, or employee of such contractor prepares, disseminates, or provides access to, any information pursuant to his employment or contract with the Commission, or his employment with such contractor.

Printed in USA. Price $\$ 1.00$. Available from the Clearinghouse for Federal Scientific and Technical Information, National Bureau of Standards,

U. S. Department of Commerce, Springfield, Virginia 
AN L- 6966

Engineering and Equipment (TID-4500, 35th Ed.)

AEC Research and

Development Report

\section{ARGONNE NATIONAL LABORATORY \\ 9700 South Cass Avenue \\ Argonne, Illinois 60440}

DESIGN OF A REMOTELY REMOVABLE

AND REPLACEABLE CRANE-BRIDGE DRIVE UNIT

FOR THE EBR-II FUEL CYCLE FACILITY

by

Johan E. A. Graae

Chemical Engineering Division

November 1.964

Operated by The University of Chicago under

Contract W-31-109-eng-38

with the

U. S. Atomic Energy Commission 
TABLE OF CONTENTS

Page

ABSTRACT ........................ 4

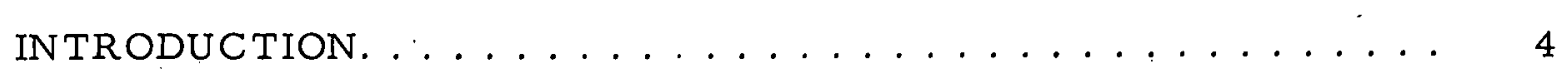

DESCRIPTION OF ORIGINALLY FURNISHED DRIVE UNIT . . . . . 6

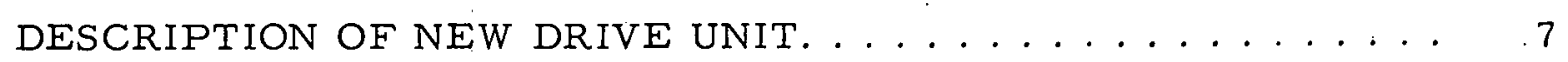

DESCRIPTION OF NEW GUIDE-PIN SYSTEM . . . . . . . . . 9

APPENDICES

A. Analysis of Failure of Original Guide-pin System . . . . . 11

B. Description of an Alternate Guide-pin System for

Very Accurate Positioning ............... 13

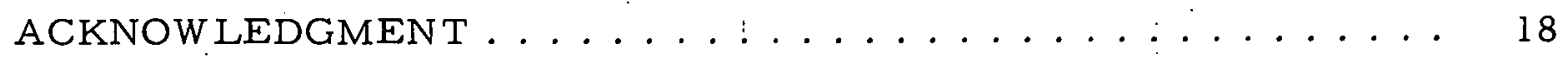

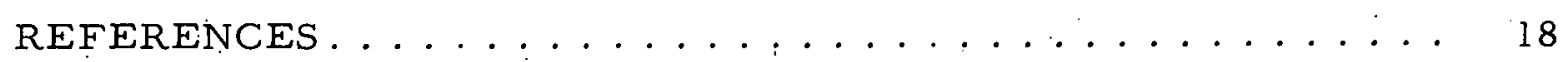




\section{LIST OF FIGURES}

No.

Title

Page

1. Circular Cell (Elevation) ................. 14

2. Bridge Drive (Original) ................ 14

3. Bridge Drive $($ New $) \ldots \ldots \ldots \ldots \ldots$

4. Installation $($ Stage 1$) \ldots \ldots \ldots \ldots$

5. Proposed Guide-pin System for Very Accurate 16

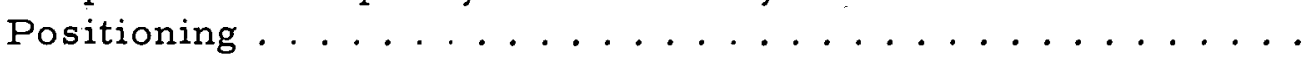

6. Composite Photo of New Drive ............. 17 


\title{
DESIGN OF A REMOTELY REMOVABLE \\ AND REPLACEABLE CRANE-BRIDGE DRIVE UNIT \\ FOR THE EBR-II FUEL CYCLE FACILITY
}

by

Johan E. A. Graae

\begin{abstract}
A remotely replaceable bridge drive unit with gear motor and electromagnetic clutch was developed for driving remotely controlled travelling crane bridges in the EBR-II Fuel Cycle Facility. The cranes are located inside a gastight, circular cell, provided with an argon atmosphere. The cell is intended for processing nuclear fuel after use in the reactor, so the radiation background will be very high. For these reasons the drive unit must be remotely. replaceable and maintainable, and protected against radiation.

The design was severely restricted by. the rather inaccessible location and the equipment provided for removal. It was also necessary to design within the space limitations of anoriginally furnished drive unit which proved inadequate.

A special novel locating pin.system was developed for precise installation of the drive unit by. remote means.
\end{abstract}

\section{INTRODUCTION}

The experimental breeder reactor (EBR-II) plant at the National Reactor Testing. Station at Idaho contains a fuel reprocessing and refabricating:building called the Fuel Cycle Facility. It is the first reprocessing plant to be integrated with a reactor and will be fully remotely. operated and maintained. Because spent and reprocessed reactor fuel material will be at elevated temperatures due to self-heating from radioactive fission products, it is necessary that the atmosphere in the cell where unclad fuel material is handled be inert and dry, containing a maximum of 1.00 ppm of oxygen plus moisture. The gamma radiation will be very intense, requiring heavy shielding and making personnel access to process and fabricating equipment impossible.

All the equipment must be replaceable and/or maintainable by remote control. Cranes and manipulators must be particularly reliable, 
since all other operations will depend on the ability of the se machines to install, remove, replace, operate, and maintain all other equipment.

The bridge drive unit which is described in this paper is used for driving two crane bridges in a circular, shielded cell, $66 \mathrm{ft}$ in diameter and $22 \mathrm{ft} 6$ in. high inside (see Figure 1). This cell contains the processing equipment. Each crane pivots around a center post at one end; the other end travels on a circular track at the outer periphery of the cell. The top of the crane bridge is about $4 \mathrm{ft}$ from the ceiling of the cell.

Each crane bridge has two drive wheels running on the outer peripheral track. Each wheel is driven by a drive unit located in a leadshielded box, which provides protection for the electric drive motor against the gamma radiation. The drive units can be operated one at a time or both at one time if required. These drive units must be removable so that in case of failure they can be taken off the bridge to be repaired.

Because of the location of the bridge drive near the ceiling of the cell and in a box on the bridge, it is not possible to observe the drive directly through the cell windows. A periscope has therefore been located in the wall at an elevation above the bridge level. This periscope is of necessity provided with radiation-resistant (optical). lenses that do not eliminate chromatic aberration but give a fuzzy picture without sharp outlines. The field of vision is limited so that only part of the drive unit can be observed.

Special equipment and other means have been provided to help overcome this poor visibility.

A special device for removal and installation of crane trolleys, manipulator carriages, and crane-bridge drive units is located on the roof of the cell and housed in a sealed steel enclosure. A roller chain with an adapter can be lowered through the roof to the floor of the cell. To this adapter can be attached lifting tools suitable for the different types of equipment to be handled. A telescoping, keyed tube, through which the roller chain passes, provides a rigid vertical movement without rotation for the upper $6 \mathrm{ft}$ of lift. This rigidity prevents rotation of the equipment being installed or removed, so that the operator only has two motions to control, namely, up and down of the removal device, and left and right of the bridge travel.

Markings on the cell wall and a pointer on the crane bridge enable an operator to position the bridge with the required accuracy, beneath the removal device.

When removal or installation of a bridge drive unit is required for maintenance or repair, the other drive unit is used for positioning the 
bridge. The drive unit to be removed must be disengaged from the drive wheel to permit this positioning. For this reason an electromagnetic clutch is provided as part of the drive unit. The clutch engages the drive unit output shaft to the bridge-wheel drive shaft once the drive unit is in place and power to the clutch is turned on. If the power fails or is turned off, the clutch disengages automatically.

To conserve headroom, the drive unit output shaft is horizontal. The alignment of this shaft with the bridge-wheel drive shaft must be good, and the drive unit must withstand the horizontal driving torque without wobbling. Bolts could not be used for securing the drive unit to the base on the crane bridge, partly because of the difficulty in reaching them and partly because of the danger of overtorque with remotely controlled tools. The removal of a broken bolt would be very difficult.

In summary, the problem was to install and remove a crane-bridge drive unit by. remote means, requiring special equipment and operating in an area of poor visibility, difficult to reach. The drive unit had to be positioned, aligned accurately, and secured so that the drive torque from the horizontal output shaft would be absorbed. Mechanical equipment for performing the remote operations was limited to two directions, namely, up and down and back and forth. No speed control other than jogging was available.

\section{DESCRIPTION OF ORIGINALLY FURNISHED DRIVE UNIT}

The original drive unit supplied by the crane manufacturer (see Figure 2) consisted of a gear motor, a solenoid-operated jaw-type clutch, and an electrical connector mounted on a steel base with four lugs at the corners. A one-inch-diameter vertical hole was drilled and reamed through each of the 3-in.-thicklugs. These holes matched four, one-inch-diameter by 4-in.-long, vertical pins mounted in the lead-shielded box on the bridge. The holes were 0.020 in. larger than the pins. The length of the holes and the pins assured that the drive unit would not wobble but would withstand the horizontal torque of the output shaft.

Remote installation and removal of the se drive units was simulated successfully in the manufacturer's shop, using a hand-operated crane but avoiding direct contact with the drives by human hands for guidance. Difficulties became apparent, however, when tests were made in the field. The special removal hoist, described in the Introduction, has just one speed ( $5 \mathrm{ft} / \mathrm{min})$. The only other motion available is that of the crane bridge (at a speed of $13 \mathrm{ft} / \mathrm{min}$ ). The absence of motion perpendicular to the bridge motion made it impossible to remove or install the bridge drive units in the field, because it made it impossible to rock the drives into plaçe. A slight tilt would cause binding between guide pins and holes (see Appendix A). 
There were other deficiencies in the original drive units. There was not sufficient freedom between the hooks on the lifting tool.and the lifting lugs on the drive units to permit the removal and replacement. The solenoid clutch did not operate satisfactorily, and the leads from motor and solenoid to the electrical connector were not easy to hook up or to disconnect remotely, even with a master-slave manipulator. This is.important for individual replacement of solenoid and motor in case of failure of either. The gear motors broke down after only a few hours of operation, partly because of poor workmanship, partly because of inadequate design, and partly because of the manner in which the solenoid clutch operated.

The gears were of the planetary type, containing cast iron, stationary, internal gear rings. Hardened-steel drive teeth, located in slots of a drum on the output shaft, were pushed in and out radially by an eccentric on the input shaft. One revolution of the eccentric would move the drive teeth one tooth on the stationary gear. This design required machining to close tolerances of the various parts of the reducers, but actual execution was not up to the required accuracy. The solenoid for the jaw clutch was shunted across two of the leads to the three-phase motor, so that every time the motor was turned on, the clutch snapped in; every time the motor was shut off, the clutch was released. This caused a large number of impacts on the drive mechanism each time the crane was operated. As a result of the combined effect of inadequate design, poor workmanship, and manner of operation, the teeth in the cast-iron ring were crushed after only a few hours of operation.

\section{DESCRIPTION OF NEW DRIVE UNIT}

Because of the inadequacies of the original bridge drive unit, a new drive unit, shown in Figure 3, was designed. It has a more rugged gear motor, a new guide-pin system, and separate electrical leads for motor and solenoid clutch. The solenoid has been made easily removable, and the electrical connector has been modified to permit remote disconnection and installation of wire leads from motor and solenoid. The clutch lever has been counterbalanced to equalize pull-in and pull-out forces on the clutch. A lead weight has been added to make the drive unit balance around the centerline so as to hang level. The changes have made the drive unit remotely removable and replaceable. They have also facilitated remote replacement of solenoid and motor with their terminals once the entire drive unit has been removed from the bridge. The design permits continuous excitation of the solenoid during operation and eliminates the repeated shocks of the clutch engaging.

The gear motor(1). is a very compact unit built on the planetarygear principle but of a different design than that of the original drive gears. Instead of the plunger-type drive teeth, solid planetary gears are 
employed, resulting in a considerable increase in the number of teeth that are in engagement at any time. The base of the unit has been precision machined with bolt holes located with an accuracy of \pm 0.001 in. There are four hold-down bolts, two of which are tight-fitting for precise positioning of the motor on the sub-base. This makes it possible to. replace the motor remotely with a new premachined unit without having to re-align the new ${ }^{*}$ unit. The 25-lb lead brick that has been added for balancing the drive unit can be lifted off for better access to the motor.

The three-phase, 60-cycle, $220-\mathrm{V}$ motor is energized by three leads. The single-phase, 60-cycle, 220-V solenoid for the clutch is energized by two leads. These five leads, consisting of type AA asbestosinsulated, \#14 gage stranded wire, are provided with wire-lugs of the fork type(2) with stops on the ends of the forks to prevent the wire lugs from slipping out from under the terminal screws on the connector. The connector consists of five spring-loaded contact plungers located in an insulating material of fiberglass-mat-reinforced polyester laminate. (3) The contact plungers are vertical brass rods, each provided with a vertical slot. A pin is pressed through the insulating material and through the slot, preventing the rods from turning, but allowing them to be depressed when pressing against the receptacle contact points on the bridge.

Tightening and loosening of the șcrews for fastening of the wire lugs to the top of the rods can be done with only a screw driver, because the contact plungers are restrained from rotating. Remote removal of the screws during dismantling and the subsequent difficult remote reinsertion of the screws at installation are avoided through the use of the fork-type wire lugs.

The solenoid for the clutch is mounted on the underside of a plate which is positioned by two guide pins and is held in place by gravity alone. The lever and yoke mechanism for the clutch is spring-loaded, so that if the jaws on the two clutch halves are not in "engage". position, the solenoid, when energized, pulls the solenoid plunger all the way into "seal" position (end of stroke) and in so doing tightens a spring which exerts a force to push the clutch into engagement. When the drive motor is started, the clutch turns until it is in the "engage" position, at which time it snaps into engagement and drives the bridge. A counterweight releases the clutch when the power is turned off. The levers and the yoke are adjusted so that there will be no axial load on the yoke when the clutch is fully engaged.

In the disengaged position, the driving clutch-half on the motoroutput shaft clears the driven clutch-half on the bridge wheel drive shaft by $1 / 16$ in. This is adequate for removal or replacement of the drive unit. 
The solenoid-operated clutch is energized separately and stays energized as long as the crane is in operation. Thus only one impact due to clutch engagement takes place for each time the crane is operated.

Figure 6 is a composite photo of the drive unit in place on the bridge. The driven shaft and the outline of the lead-shielded box are shown.

\section{DESCRIPTION OF NEW GUIDE-PIN SYSTEM}

The new guide-pin system for the bridge drive unit is shown in Figures. 3 and 4. It consists of two locating pins, one long and one short, mounted on the base on which the equipment is to be placed. The top of each pin is tapered to provide lead in.

The bridge drive unit has three guide holes. Two of these holes are placed in line, one above the other. These two holes are to engage the long guide pin. The third hole is placed so that it will engage the short guide pin. The hole at $A$ (see Figures 3 and 4 ) is shallow and slightly larger than the guide pin, which permits a substantial tilt of the drive unit during installation and removal without causing binding between hole and pin. The holes at $B$ and $C$ are oblong, permitting a lot of freedom in one direction, but only little more than a slip fit in the direction perpendicular to it.

The long guide pin is 1.250 in. in diameter. Hole $A$ is 1.260 in. in diameter and $1 / 8$ in. deep, with rounded edges. With these dimensions the drive unit can be 2 in. out of level in 25 in. (that is, a $4 \frac{10}{2}$ tilt) without binding. The hole at $C$ is 2 in. long by $1.260 \mathrm{in}$. wide and $3 / 8$ in. deep. The pin at $B$ does not have to resist bending, so it is only 0.999 in. in diameter. The hole at $B$ is oblong, $1 \frac{3}{4}$ in. by 1.010 in., and $1 / 8$ in. deep.

The long guide pin, when fully engaged in the two holes $A$ and $C$, resists torque from the horizontal output shaft. The two holes at $A$ and $B$, when engaged on the guide pins, locate the drive unit in a horizontal plane. The machined base on the bridge and the machined underside of the drive unit assure that the output drive shaft will be level with the driven shaft.

During construction, the guide pins are located by installing the drive unit with the pins in place, but not bolted down. The clearance between guide pins and holes is fitted with shimstock to center the pins in the holes. The drive unit is adjusted until the drive shaft is properly aligned with the driven shaft. The guide pins are then bolted down. The drive unit and the shims are removed and the pins are doweled in place. 
The sequence of stages for placing one of the bridge drives in one of the lead shielded boxes on the bridge is as follows (see Figure 4).

Stage 1

The bridge drive unit is lifted by a special lifting tool, attached to the removal hoist, from the cell floor to an elevation above the crane bridge. The bridge is moved (by the other drive unit) into position under the drive unit, and the unit is lowered so that the long locating pin enters hole A.

Stage 2

The tapered point of the long guide pin acts as lead-in to engage the second hole at $\mathrm{C}$ as the equipment is lowered. As the pin becomes fully engaged in $C$, the drive unit levels off in the direction perpendicular to the shaft. The hole at $B$ is partly engaged.

Stage 3

The drive unit continues to move downward, and as it settles on the precision-machined base, horizontal tilt is eliminated and the guide pin at $B$ engages the hole at $B$ fully. During the last part of the downward travel, when the drive unit is properly aligned by having the three holes at $A, B$, and $C$ engaged on the guide pins, five spring-loaded, electrical contacts press against five acorn nut terminals on the base.

The drive unit is now properly. in place with the clutch ready for operation.

The lifting tool is disengaged by moving the bridge, and the tool is lowered to the floor, where it can be removed from the removal hoist.

Due to clearance fits between the lifting tool and the removal hoist mechanism, and because the line of lift does not coincide with the center of gravity, the drive unit will not hang level. However, the tilt will be much less than the maximum permissible tilt of $4 \frac{1}{2}^{\circ}$ shown in Figure 4.

Removal of the drive unit is accomplished by disengaging the drive clutch and lifting the unit up vertically with the special removal hoist.

The described locating system allows precise installation of the drive equipment by remote means. It allows for substantial initial misalignment, in all directions, which is corrected automatically as the equipment slips into place. It eliminates the use of hold-down bolts, and it permits transmittal of the torque exerted by the horizontal output shaft of the drive. 


\section{APPENDIX A}

Analysis of Failure of Original Guide-pin System (see page 6)

The following drawing illustrates why a long guide pin tends to bind in a long straight hole.

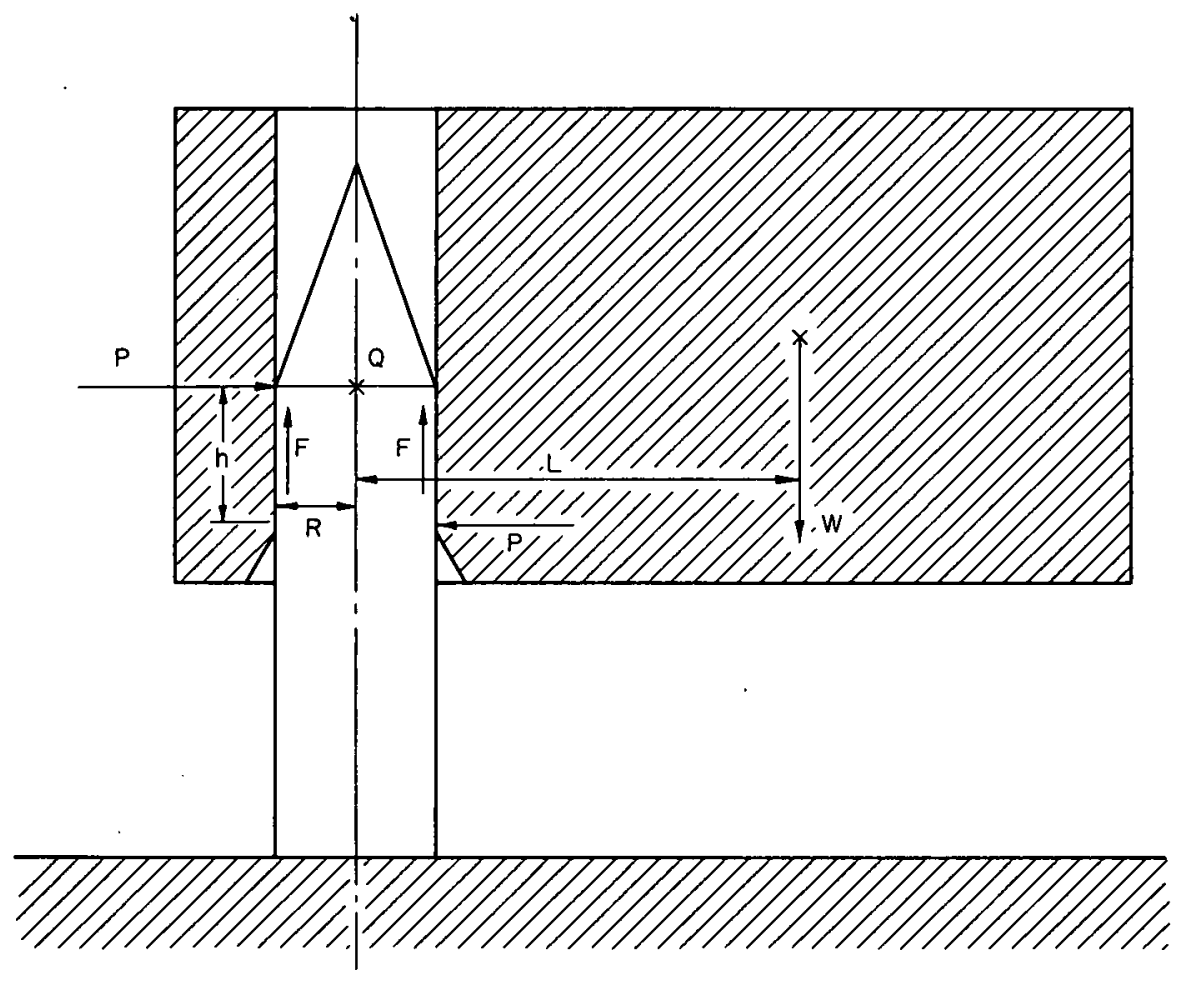

used:

In the figure and the calculations the following nomenclature is

$\mathrm{h}=$ vertical length of engagement between pin and hole;

$\mathrm{L}=$ horizontal distance between centerline of pin and center of gravity of equipment;

$\mathrm{W}=$ weight of equipment;

$P=$ horizontal force between pin and hole;

$f=$ coefficient of friction;

$F=$ frictional force between pin and hole.

For the system at rest, the sum of the frictional forces equals the weight: $2 F=W$. 
The sum of the moments of the forces on the equipment about $Q$ are zero:

$$
W L+(-P h)+F R-F R=0
$$

so that

$$
P=W(L / h)
$$

Now the friction force is given by

$$
F=f P=f W(L / h) \text {. }
$$

The condition for not binding is:

$$
2 F<W
$$

or

$$
2 \mathrm{fW} L / \mathrm{h}<\mathrm{W},
$$

or

$$
2 f \mathrm{~L} / \mathrm{h}<\mathrm{l} \text {. }
$$

Assume that $f=0.2$ for steel on hardened steel. Then the condition that no binding occurs is

$$
(2)(0.2)(. \mathrm{I} / \mathrm{h})<1
$$

or :

$$
\mathrm{L} / \mathrm{h}<2.5
$$

In the original bridge drive the distance $L$ from guide pin to center of gravity of the drive unit was about 12 in. In order not to cause binding, $h$ would have to be greater than $12 / 2.5=4.8 \mathrm{in}$.

Since $h$ is zero when the pin enters the hole and 3 in. when the pin is fully engaged, it is evident that the slightest tilt of the bridge drive unit would cause binding at any stage of installation or removal.

Relieving the pin would have caused difficulties with hanging up on the lower shoulder of the relief. Relieving the hole would have been better. This is in effect what has been done to the new guide-pin system shown in Figures 3 and 4 . Making the holes oblong at $B$ and $C$ eliminates binding in one direction and retains the snugness required in the other direction. 


\section{APPENDIX B \\ Description of an Alternate Guide-pin System \\ for Very Accurate Positioning}

An alternate guide-pin system leading to very accurate ( $\pm 0.001 \mathrm{in.})$ positioning is shown in Figure 5. This system uses round holes only. The long pin has two diameters: one used for initial rough lead-in, and the other for accurate final positioning. This system was not used for the redesigned bridge drive units because it was not conceived at that time.

The figure shows two interim positions. Figure 5A shows the considerable degree of freedom allowed during the initial engagement. Figure $5 \mathrm{~B}$ shows the long pin fully engaged and the short pin about to become fully engaged. The remaining travel can be used for precise matching of contacts or drive mechanism alignments.

This guide-pin system might be useful for drive units with vertical drive shafts as well as for drive units with horizontal drive shafts. It eliminates the tendency of guide pins to bind in the guide holes and allows the guide pins to be large so they can be seen during remote operations. The permissible tilt can be made large enough to be easily observed and corrected if necessary. 
Figure 1

CIRCULAR CELL (ELEVATION)

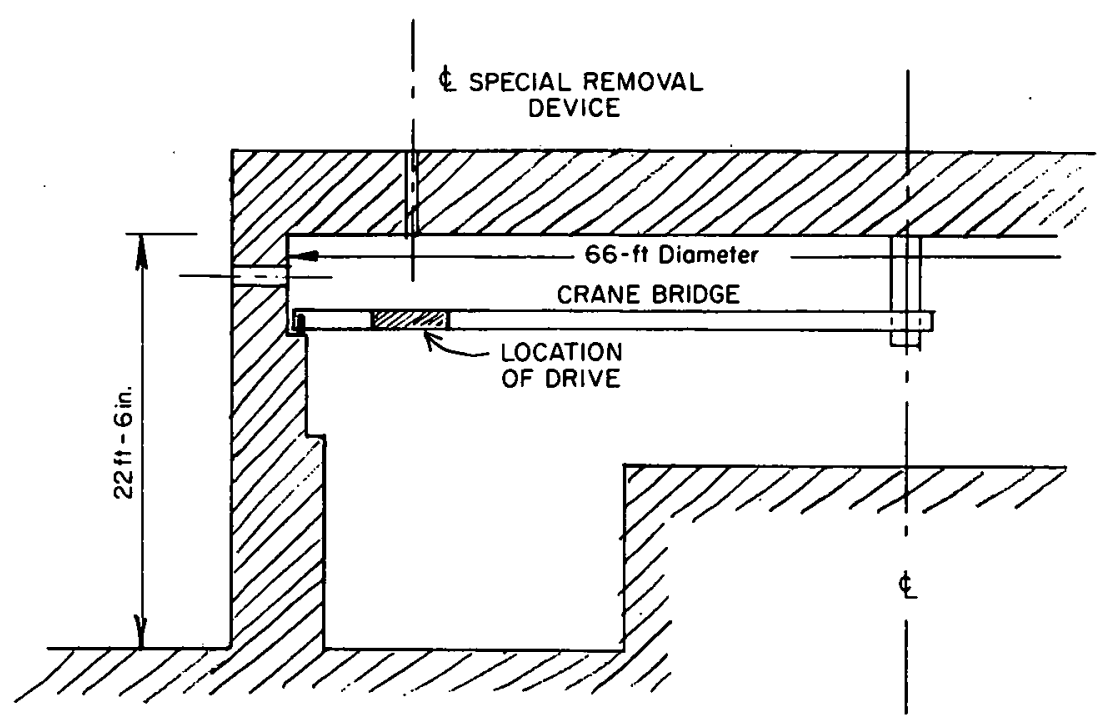

Figure 2

BRIDGE DRIVE (ORIGINAL)

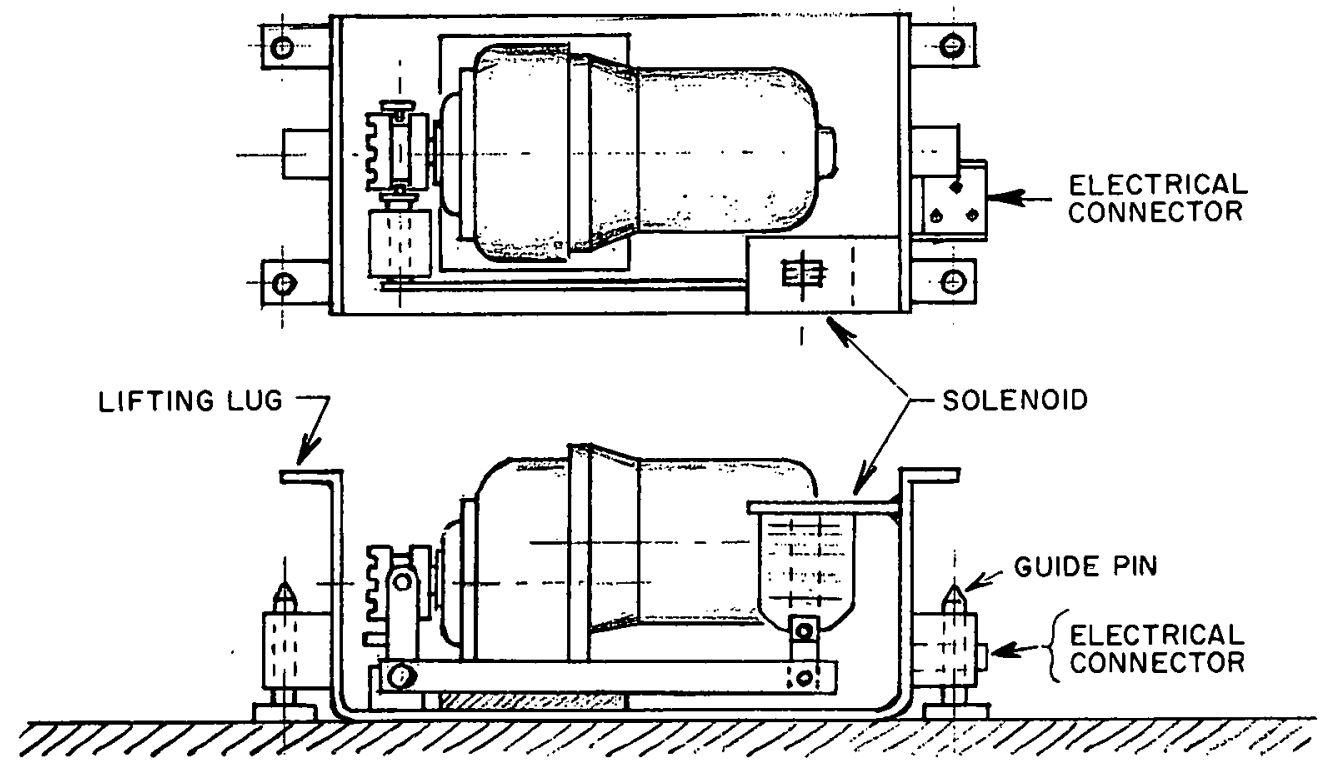


Figure 3

BRIDGE DRIVE (NEW)

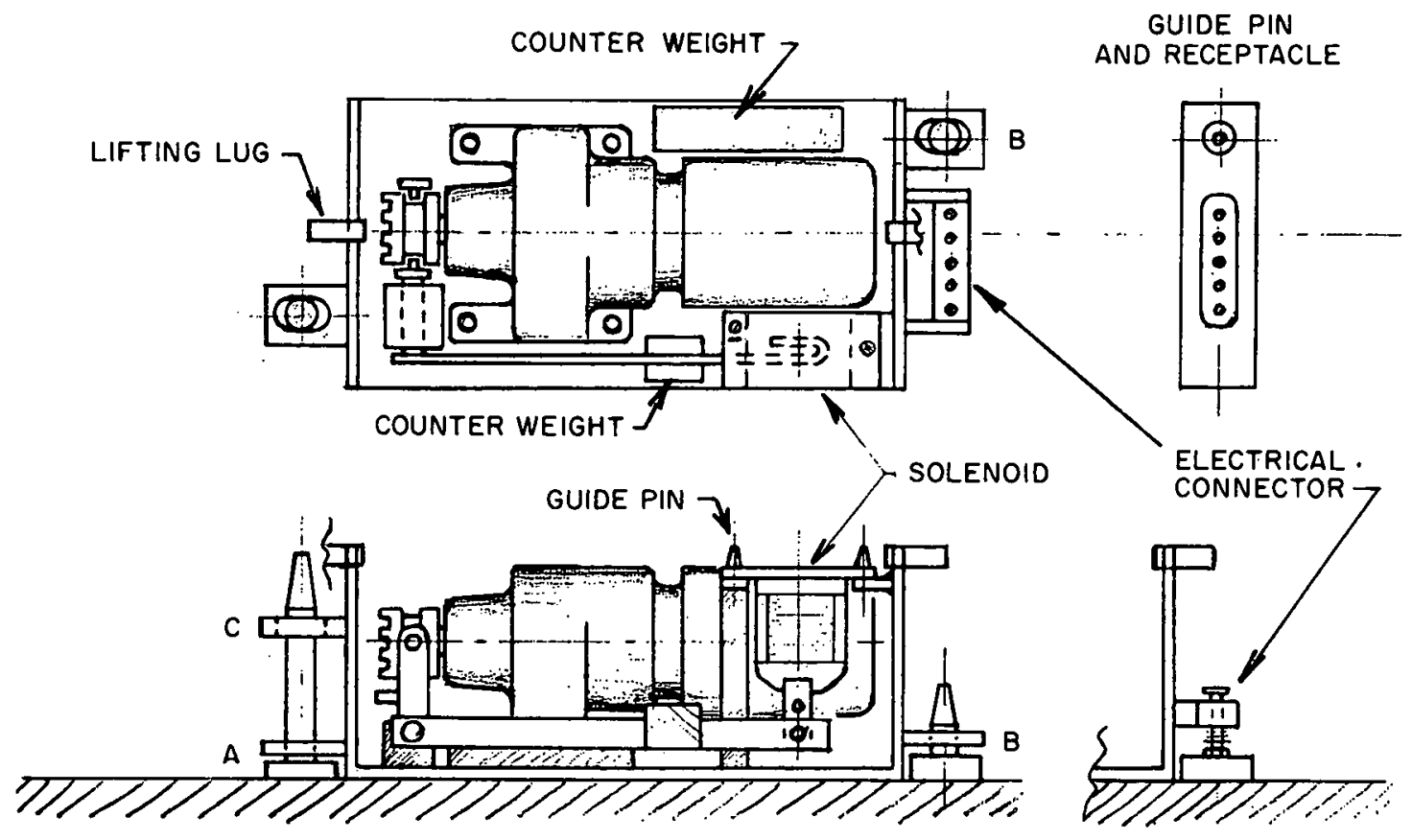

Figure 4

INSTALLATION (STAGE 1)

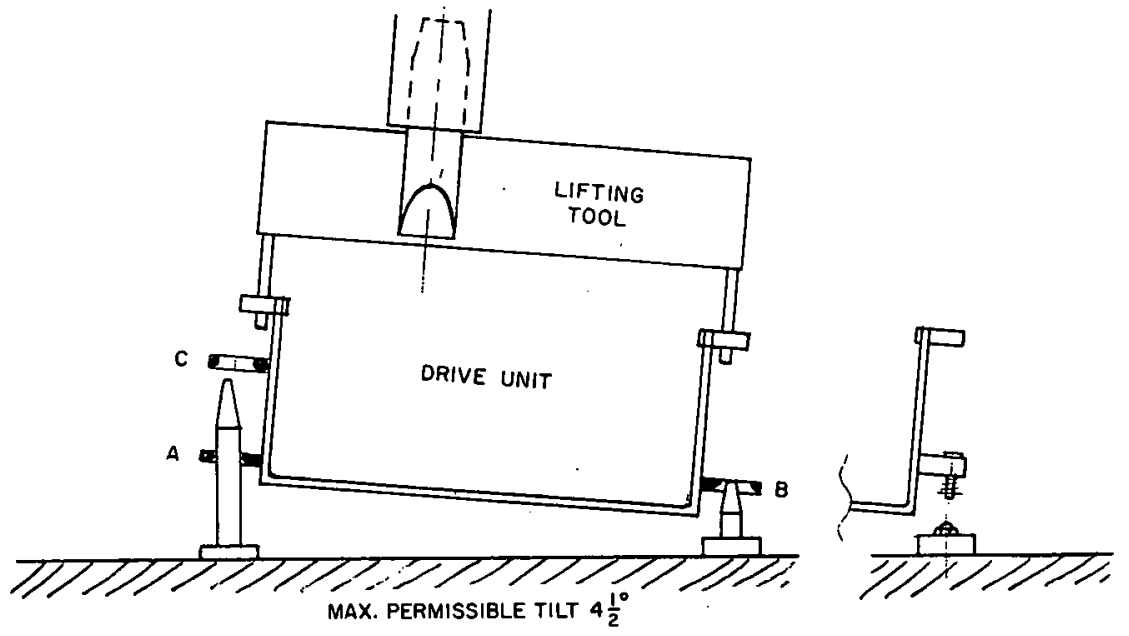


Figure 5

PROPOSED GUIDE-PIN SYSTEM FOR VERY ACCURATE POSITIONING
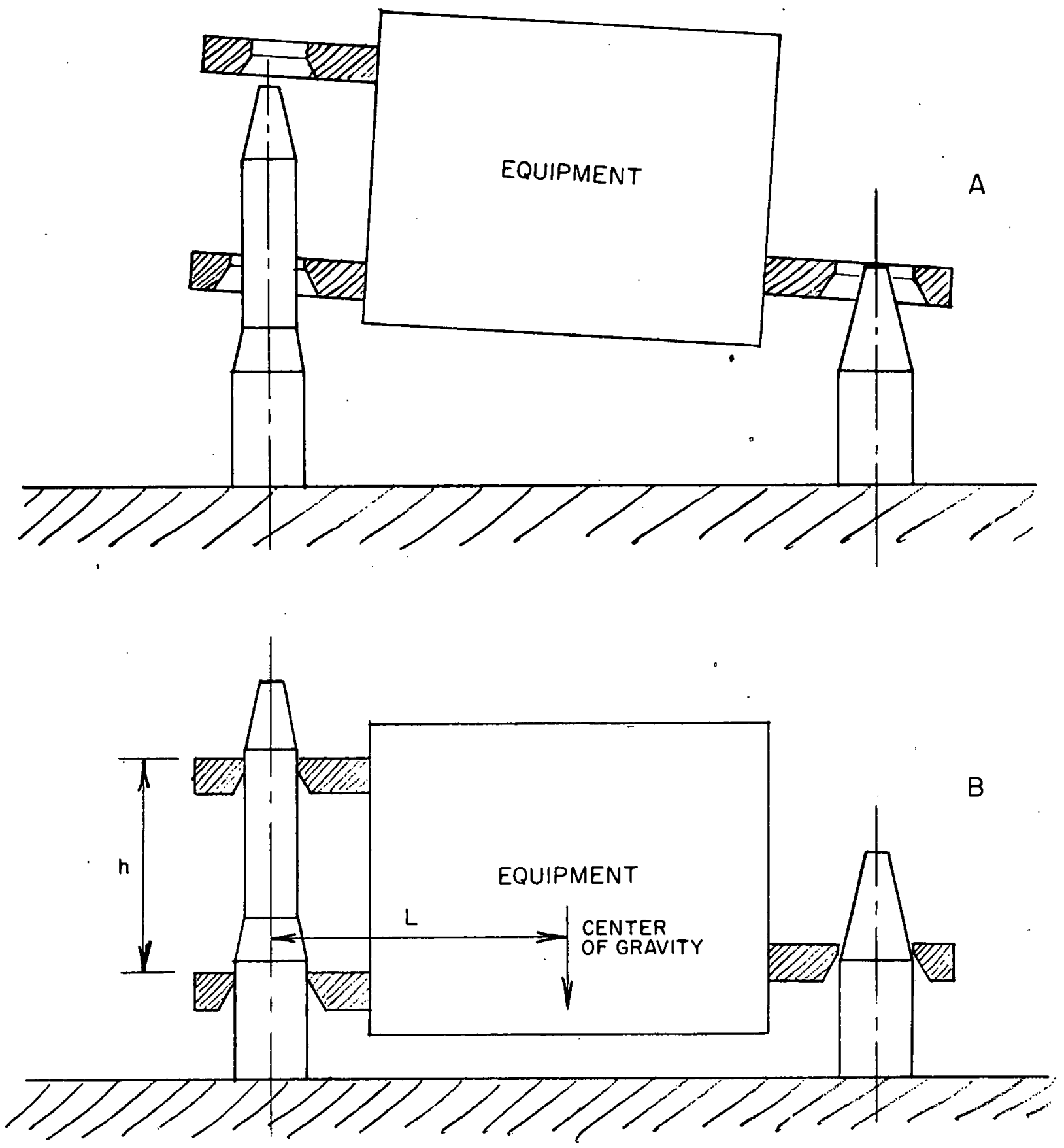


\section{$\bullet$}

Figure 6

COMPOSITE PHOTO OF NEW DRIVE

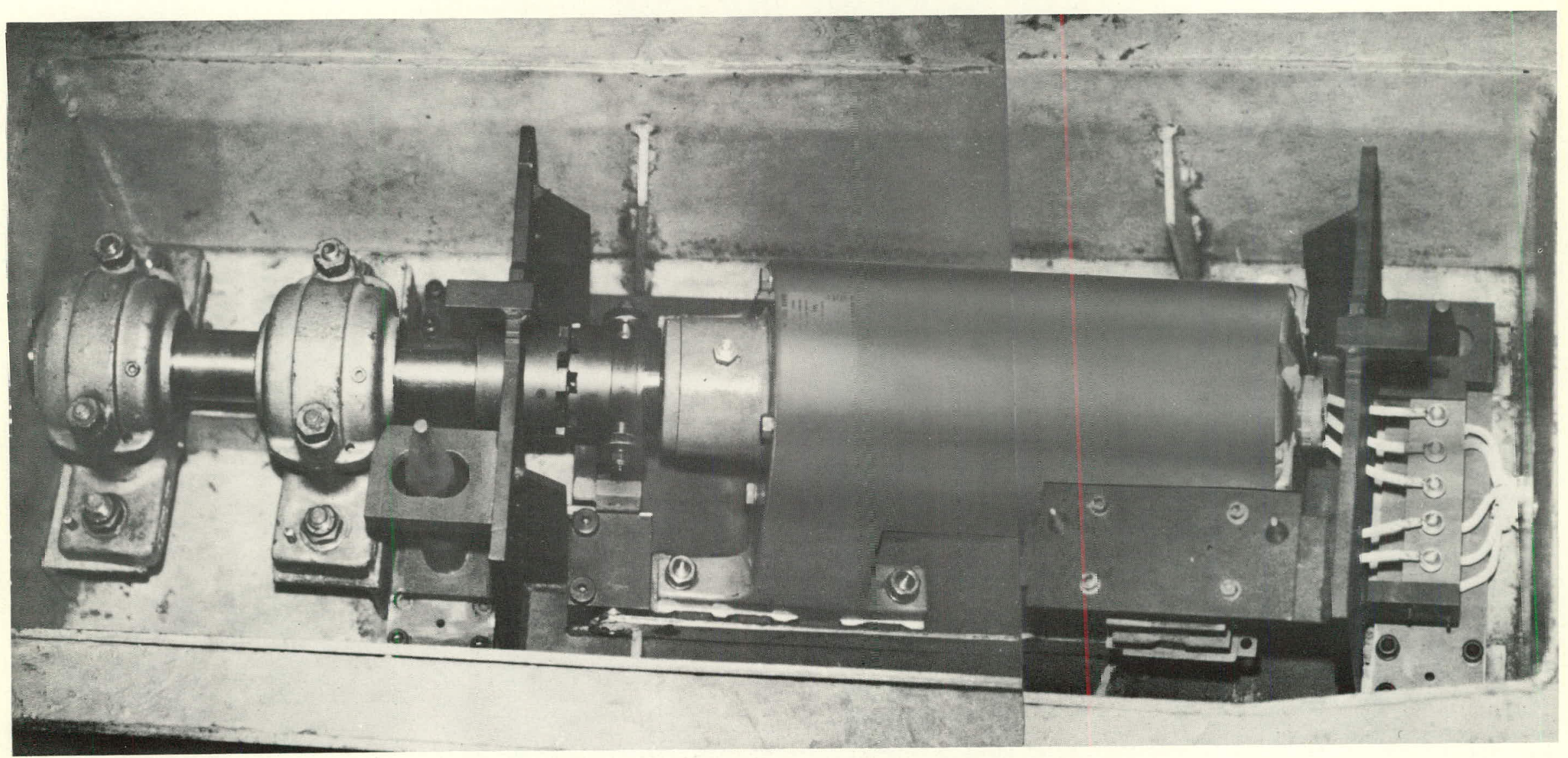


The author wishes to acknowledge the assistance of $\mathrm{R}$. Vree in the design of the equipment, and of W. Voss in the installation and testing of the equipment in the field.

\section{REFERENCES}

1. Hi-Range reduction drive, Model HR-50-FD, 345 to 1 gear ratio, l/4-hp, GE motor, directly mounted. Built by Black Tool, Inc., Denver, Colorado. Now owned by Ferguson Machine Company, Divison of Universal Clutch Corporation.

2. Burndy Fork-tongue Hylug No. YAV 14-Z6.

3. Glastic Grade GF-184, The Glastic Corporation, Cleveland, Ohio. 